\title{
Eksistensi Prasasti Tungku Tigo Sejarang di Nagari Tuo Pariangan
}

\author{
Hari Darmansyah ${ }^{1}$, Yuliantoro ${ }^{2}$, Asyrul Fikri ${ }^{3}$ \\ 1,2,3 Universitas Riau \\ hari.darmansyah2127@student.unri.ac.id \\ yuliantoro@lecturer.unri.ac.id \\ asyrul.fikri@lecturer.unri.ac.id
}

\begin{abstract}
Abstrak
Prasasti Pariangan adalah prasasti yang ditemukan di Nagari Tuo Pariangan. Nagari Tuo Pariangan adalah sebuah desa yang terletak di Gunung Marapi di Kecamatan Pariangan, Kabupaten Tanah Datar, Provinsi Sumatera Barat. Kajian ini menjelaskan tentang sejarah Nagari Tuo Pariangan dan proses ditemukannya prasasti ini, serta bagaimana kondisinya saat ini. Penelitian ini bertujuan untuk mengetahui bagaimana sejarah prasasti Pariangan atau yang sekarang lebih dikenal dengan prasasti tungku Tigo Sejarang oleh masyarakat sekitar. Metode penelitian yang digunakan adalah penelitian kualitatif dengan menggunakan analisis dan menonjolkan proses dan maknanya. Hasil penelitian menunjukkan bahwa Prasasti Pariangan tahun 1340 dibuat oleh Raja Adityawarman. Sesuai dengan namanya prasasti tungku Tigo Sejarang terdiri dari tiga batu besar dengan jarak antara ketiga batu tersebut tidak terlalu jauh dan jika dilihat dari tempat yang lebih tinggi akan terlihat seperti tungku segitiga tradisional. Pada tahun 2021, Dinas Pariwisata Kota Padang membantu dan merestorasi prasasti ini. Saat ini prasasti tersebut masih dalam tahap pemugaran.
\end{abstract}

Kata Kunci: Sejarah, Prasasti, Nagari Pariangan, Pemugaran

\begin{abstract}
Pariangan inscription is an inscription found in Nagari Tuo Pariangan. Nagari Tuo Pariangan is a village located on Mount Marapi in Pariangan District, Tanah Datar Regency, West Sumatra Province. This study explains the history of Nagari Tuo Pariangan and the process of finding this inscription, and how its current condition is. This study aims to determine how the local community's history of the Pariangan inscription or what is now better known as the Tigo Sejarang furnace inscription. The research method used qualitative research to analyze and highlight the process and meaning. The results showed that the Pariangan inscription in 1340 by King Adityawarman. As the name implies Tigo Sejarang furnace inscription consists of three large stones with the distance between the three stones is not too far and, when viewed from a higher place, will look like a traditional triangular stove. In 2021, the Padang City Tourism Office assisted and restored this inscription. Currently, the inscription is still in the stage of restoration.
\end{abstract}

Keywords: History, Inscription, Nagari Pariangan, Restoration.

Jurnal Humanitas is licensed under a Creative Commons AttributionShareAlike 4.0 International License. 


\section{Pendahuluan}

Sejarah sebuah prasasti bukan lah sesuatu yang baru dibicarakan. Prasasti merupakan salah satu sumber sejarah dan di setiap prasasti tentunya mempunyai sejarahnya masingmasing. Sejarah merupakan sesuatu yang tidak terpisahkan dalam kehidupan manusia. Mempelajari sejarah merupakan suatu kegiatan yang selalu berkelanjutan yang dilakukan oleh manusia dalam hidupnya. Seiring dengan perjalanan sejarah tersebut, akan selalu ada dan muncul benda-benda atau apapun itu yang menjadi bukti dari perjalanan sejarah itu.

Sejarah dalam bahasa Indonesia berasal dari bahasa Melayu yang menyerap kata syajarah dari bahasa Arab yang berarti pohon, keturunan, asal-usul, silsilah, riwayat. Kata ini masuk kedalam bahasa Melayu setelah akulturasi budaya pada sekitar abad ke-13. Akulturasi yang kedua yaitu ketika masuknya kebudayaan Barat pada abad ke-15 yang membawa kata historie (Belanda), history (Inggris) berasal dari bahasa Yunani, istoria yang berarti ilmu. Sejarah merupakan cabang ilmu pengetahuan yang mengkaji secara sistematis keseluruhan perkembangan, proses perubahan atau dinamika kehidupan masyarakat dengan segala aspek kehidupannya yang terjadi dimasa lampau (Madjid \& Wahyudhi, 2014: 7-8).

Sejarah bertjuan mengembangkan kepribadian setiap orang yang mempelajarinya. Hal ini dikarenakan dengan belajar sejarah menyebabkan kesadaran masyarakat meningkat dalam keterikatannya dengan manusia lain sebagai suatu komunitas. Kita dapat mengambil berbagai inspirasi dalam sebuah kisah sejarah, semua itu dapat membantu kita untuk menjadikan masa depan menjadi lebih baik. Dalam mempelajari sejarah, kita akan dihadapkan dengan berbagai sumber sejarah yang mendukung suatu penelitian sejarah. Ketika seorang sejarawan hendak menuliskan kisah masa lampau, usaha pertama adalah mencari atau menemukan jejak-jejak (traces) yang ditinggalkan. Istilah "jejak-jejak", ini diperkenalkan oleh pemikir Perancis, Langlois dan Eignobos. Serangkaian peristiwa biasanya selalu meninggalkan jejak. Jadi, harus dicari hubungan antara jejak yang ditinggalkan dengan peristiwa (event). Jejak-jejak masa lampau itu dikenal dengan sebutan sumber sejarah (historical sources) (Herlina, 2020: 7).

Sumber sejarah banyak jenisnya, mulai dari sumber tertulis, sumber lisan dan sumber benda (artefak). Salah satu sumber sejarah tertulis adalah prasasti. Prasasti tungku tigo sejarang atau yang dahulu dikenal sebagai prasasti Pariangan merupakan salah satu prasasti yang terdapat di nagari tuo Pariangan. Di lereng gunung Marapi di Provinsi Sumatra Barat, 
tepatnya di Kabupaten Tanah Datar, Kecamatan Pariangan pada ketinggian 500-700 M di atas permukaan laut terdapat sebuah nagari yang bernama nagari tuo Pariangan. Kabupaten Tanah Datar ini sendiri terdiri dari 14 kecamatan, 75 nagari dan 395 jorong. Nagari Pariangan merupakan nagari tertua di Minangkabau berdasarkan Tambo Minangkabau. Tambo adalah uraian sejarah suatu daerah yang seringkali bercampur dengan dongeng. Tambo di Minangkabau adalah sejarah, kisah yang merupakan warisan turun temurun tentang asal usul Minangkabau yang disampaikan secara lisan oleh tukang kaba pada upacara adat (Zainuddin, 2013: 3). Tambo-tambo tersebut kemudian dibukukan berdasarkan apa-apa saja yang dikisahkannya sehingga masing-masing isi tambo tidak ada yang sama.

Nagari adalah sebutan bagi suatu kesatuan sosial penduduk yang berdasarkan pada kebatinan dan kebudayaan serta memiliki hak otonomi sendiri untuk wilayahnya. Nagari merupakan nama tradisional dan unit politik dari organisasi sosial-politik Minangkabau sejak zaman pra-kolonial (von Benda-Beckman, 2001: 9), yang mana saat ini juga merupakan unit pemerintahan terendah di Provinsi Sumatera Barat (Melinda, 2006). Di nagari Pariangan terdapat 22 suku dan 22 niniak mamak suku serta 101 Niniak mamak Paruik, yang disesuaikan dengan adat salingka nagari Pariangan. Pariangan juga merupakan sebuah nagari tempat awal mula sejarah nenek moyang orang Minangkabau. Hal ini juga dimuat didalam Tambo Minangkabau dan tuturan yang ada.

Pariangan mendapatkan sebutan desa terindah versi majalah Travel Budget Magazine USA, edisi 24 Februari 2012, ada 16 kota yang indah di dunia. Di antaranya ada nagari Pariangan yang indah karena alam dan budayanya. Travel Budget Magazine USA adalah majalah bertaraf internasional yang merilis hasil survey terhadap opini serta penilaian dari travelers yang pernah berkunjung ke nagari Pariangan. Mereka menjaring sekitar 2000 angket berupa survey yang diisi oleh wisatawan yang pernah mengunjungi beberapa desadesa yang indah di dunia (Erwin, Warhat, \& Syafwandi, 2021: 129).

Setelah terisi seluruh angket yang disebar oleh pihak Travel Budget Magazine USA yang totalnya berjumlah dua ribu, kemudian di buatlah sebuah analisis statistik yang menghasilkan keputusan bahwa terdapat 5 buah desa yang dianggap indah oleh wisatawan. 5 desa tersebut adalah Nagari Pariangan di Indonesia, desa Wengen di Swiss, Cesky Krumlov di Ceko, Eze di Perancis, dan Niagara on the Lake di Kanada. Setelah dikategorikan apa saja poin-poin yang indah dari setiap desa tersebut, nagari Pariangan 
unggul dengan indeginous culture-nya yang masih sangat terjaga. Maksud dari indeginous culture tersebut adalah Nagari Pariangan menjadi yang terbaik dari segi pemeliharaan dan pelestarian budayanya dibanding dengan desa-desa lainnya. Seluruh karya tulis berupa beberapa buku mengenai sejarah Nagari Pariangan, arsitektur rumah adat Minangkabau yaitu rumah gadang, serta beberapa naskah kuno yang menuliskan hukum adat dan kearifan-kearifan lokal masih tersimpan dengan baik di Nagari Pariangan hingga kini. Paduan harmonisasi pertumbuhan alam, sejarah, masyarakat beserta kebudayaan juga menjadi alasannya.

Belum ada penelitian khusus mengenai sejarah prasasti ini, penelitian-penelitian sebelumnya hanya membahas seputar daya tarik wisata dan penjelasan singkat mengenai apa saja tempat-tempat yang dapat menjadi potensi daya tarik wisata di Nagari Pariangan atau yang terdapat di Kabupaten Tanah Datar, Provinsi Sumatera Barat. Beberapa contoh penelitian sebelumnya tersebut seperti penelitian yang berjudul "Potensi Daya Tarik Wisata Nagari Tuo Pariangan Sebagai Kawasan Desa Wisata Pariangan Kabupaten Tanah Datar Sumatera Barat" karya Masly (2017. Ada juga penelitian yang berjudul "Pengembangan Objek Wisata Panorama Tertinggal di Kabupaten Tanah Datar" karya Momon dt. Tanamir (Tanamir, 2017). Kemudian penelitian dengan judul "Brand Identity Nagari Pariangan, Desa Terindah di Dunia Kabupaten Tanah Datar, Sumatera Barat" (Erwin, Warhat, \& Syafwandi, 2021).

Dalam penelitian ini dijabarkan mengenai bagaimana sejarah Nagari Tuo Pariangan, proses ditemukannya prasasti Pariangan atau Prasasti Tungku Tigo Sejarang serta bagaimana kondisinya saat ini. Tujuan penelitian ini adalah untuk mengetahui sejarah nagari Pariangan secara umum dan eksistensi prasasti Pariangan atau prasasti Tungku Tigo Sejarang. Penelitian ini penting karena pada awalnya hanya ditemukan sebuah batu yang dikenal dengan sebutan prasasti Pariangan. Namun ternyata terdapat 2 batu yang serupa dengan batu prasasti Pariangan. Setelah diperhatikan ternyata ketiga batu tersebut berada dikisaran jarak yang relatif sama antarketiganya. Jika dilihat dari tempat yang lebih tinggi, ketiga batu tersebut berbentuk segitiga seperti sebuah tungku tradisional dari batu sehingga disebut sebagai prasasti Tungku Tigo Sejarang yang terdapat di Nagari Tuo Pariangan. 


\section{Metode Penelitian}

Penelitian ini menggunakan metode penelitian kualitatif. Metode penelitian kualitatif adalah metode penelitian deskriptif yang cenderung menggunakan analisis, penelitian ini lebih menonjolkan proses dan makna. Ibnu Hajar (1996) menjelaskan bahwa dari segi hasil penelitian yang disajikan, penelitian kualitatif menyajikan hasilnya dalam bentuk deskripsi naratif (Salim \& Syahrum, 2012). Jawaban dari pertanyaan tentang apa (what), bagaimana (how), dan mengapa (why) atas suatu fenomena didapatkan dengan menggunakan metode kualitatif. Teknik pengumpulan data yang digunakan adalah teknik observasi dan wawancara. Observasi merupakan salah satu upaya untuk dapat melakukan pengamatan secara langsung dan sistematis dalam suatu proses penelitian. Setelah dilakukan observasi, data-data yang dihasilkan kemudian dicatat sebagai catatan observasi. Sementara wawancara adalah cara pengumpulan data yang dilakukan dengan bertanya dan mendengarkan jawaban langsung dari sumber utama data. Penulis merupakan pewawancara dan sumber data adalah orang yang diwawancarai. Analisis data dilakukan melalui analisis induksi dengan tahapan reduksi data, penyajian data, dan penarikan kesimpulan.

\section{Pembahasan}

\section{Sejarah Nagari Tuo Pariangan}

Nagari pertama di ranah Minang adalah Nagari Pariangan. Kemudian muncul Nagari Padang Panjang. Nagari Pariangan dan Padang Panjang dikenal sebagai nagari kembar karena letaknya yang berdekatan. Kedua Nagari ini terletak di lereng sebelah Selatan Gunung Marapi. Menurut Tambo Minangkabau di negeri itulah Sri Maharajo Dirajo memulai mengatur susunan negeri-negeri selingkungan gunung Marapi dan Sago yang kemudian berkembang menjadi Minangkabau (Amir, 2006: 147).

Gunung Marapi merupakan daerah yang ditempatkan oleh sejarah adat Minangkabau sebagai pusat jala tumpukan ikan, tempat bermukimnya tokoh-tokoh sejarah seperti Sri Maharajo Dirajo, Dt. Perpatih nan Sabatang, Adityawarman, Bundo Kandung dan lainlain. Dalam pemetaan adat Minangkabau, gunung Marapi ibarat "titik triangulasi primer". Oleh karena itu, apa yang dikatakan berkaitan dengan keminangkabauan umpamanya gelar-gelar pusaka waris (datuk), jika dikaji silsilahnya berasal dari daerah gunung Marapi sebagai daerah inti (nucleus) Minangkabau. Sri Maharajo Dirajo adalah raja pertama yang 
datang ke Minangkabau. Beliau merupakan anak ketiga atau anak terakhir dari Iskandar Zulkarnain. Sri Maharajo Dirajo mempunyai dua saudara, yaitu Sultan Maharaja Alif yang merupakan seorang raja di sebuah benua bernama Rum dan Sultan Maharajo Dipang yang merupakan raja di benua Cina. Secara tersirat, tambo alam Minangkabau telah menjajarkan kerajaan Minangkabau sejajar dengan kerajaan yang ada di benua Eropa dan Cina.

Alasan diberi nama "Pariangan" adalah karena pada masa awal terbentuknya perkampungan, suasana masyarakatnya senantiasa dalam kondisi riang sehingga Ninik Sri Maharaja Diraja dan Cateri Bilang Pandai berkeinginan untuk mengganti nama kampung itu dengan nama Pariangan (Diradjo, 2017: 11).

Nagari Pariangan dikenal menjadi Tampuk Tangkai Alam Minangkabau oleh masyarakat sekitarnya. Untuk menggambarkan asal-usul nenek moyang masyarakat Minang tersebut, terdapat sebuah pantun yang sangat familiar di kalangan masyarakat Minang, yaitu:

Dari mano titiek palito

di baliek telong nan batali

Dari mano asa niniek kito

dari puncak gunung Marapi

Dipatah rantiang sikakau

dipatah dipasilangkan

Takambang adat di Minangkabau

Batumpuak di Pariangan

Di sinan adat nan bagantang

Gantang sipuluik jo padi

Di sinan adat mulo dikambang

Kambang nan tidak kuncuik lai
Dari mana titik pelita

di balik tenglong yang bertali

Dari mana asal ninik kita

dari puncak gunung Merapi

Dipatah ranting Sikakau

dipatah dipersilangkan

Terkembang adat di Minangkabau

Bertumpuk di Pariangan

Di sana adat yang bergantang

Gantang beras pulut dan padi

Disana adat mula dikembang

Kembang yang tidak kuncup lagi (Amir, 2006: 166).

Masyarakat menganut falsafah “adat basandi sarak, sarak basandi Kitabbullah” dan merupakan salah satu ciri spesifik lain dari nagari ini. Nilai-nilai dasar yang terkandung pada falsafah adat basandi sarak, sarak basandi Kitabbullah adalah kehidupan masyarakat 
Minangkabau secara umum, dan Nagari Pariangan secara khusus dibangun berdasarkan syari'at Islam yang terkandung pada Al Qur'an dan Hadist (Irman et al., 2020: 53).

Tidak hanya dikenal sebagai asal-mula masyarakat Minangkabau, nagari tuo Pariangan juga dikenal sebagai asal-muasal nagari. Suku dan nagari merupakan sesuatu yang amat penting bagi orang Minang. Suku adalah unit terkecil dalam sistem kekerabatan orang Minang, sementara nagari adalah unit terbesar dalam sistem kekerabatan orang Minang. Keterangan terbaik mengenai asal usul nagari menurut Rusli Amran ialah yang diberikan oleh ahli adat De Rooy.

Menurut cerita lama, tulis De Rooy, Nagari yang tertua adalah Pariangan, Padang Panjang. Dari Pariangan, rakyat mengembara kemana-mana dan mendirikan tempat-tempat tinggal yang baru di sekitarnya. Hubungan antara keluarga di tempat baru dengan keluarga asal tetap dijaga dan menjadi alasan untuk saling kunjung-mengunjungi atau untuk mengundang menghadiri hajatan tertentu. Di tempat yang baru itu mereka hidup dengan bercocok tanam, menangkap ikan atau berburu. Mereka sering pula berkelana ke daerah sekeliling, dimana pohon-pohon hutan masih harus ditebang dan diberi tanda bahwa kawasan itu sudah ada yang menggarap. Tanda ini kelak dipakai sebagai bukti bahwa mereka berhak atas tanah di situ yang akan mereka kerjakan nanti atau disediakan sebagai cadangan untuk bercocok tanam (Amir, 2011: 39).

Ada versi lain yang menyebutkan bahwa penduduk Nagari Pariangan berasal dari penduduk Hindia belakang yang pindah ke arah selatan sebagai dampak dari serangan bangsa lain dari Utara (Eropa). Para penduduk tersebut awalnya berlayar dan bermukim di tepi pantai Timur pulau Sumatera. Kemudian mereka berlayar menelusuri sungai-sungai dari muara sampai ke hulu atau pedalaman dan akhirnya sampai juga ke Nagari Pariangan.

Kemudian seiring waktu berlalu, banyak pendatang-pendatang baru yang datang dan menetap disekitar daerah tersebut. Pada awalnya masyarakat sekitar hanya menggarap tanah yang terdapat di puncak-puncak bukit, namun kemudian mereka mulai berani menjarah ke lereng atau daerah-daerah dataran rendah serta lembah-lembah dikaki bukit yang subur dan banyak terdapat air. Mereka bertani dan bercocok tanam, beternak hewan serta menetap disana. Nenek moyang kita tersebut lambat laun paham bahwa tanah-tanah dapat tetap subur dan ditanami ulang sepanjang tahun dengan air yang mengalir dari hutanhutan yang lebat untuk mengairi sawah-sawah dilembah-lembah dan dataran rendah. Dari hal inilah muncul falsafah adat "Alam takambang jadi Guru" dalam masyarakat Minang. 
Dalam proses pembentukan menjadi Nagari Pariangan, harus melalui 4 tahap sesuai dengan logika penyebaran penduduk sebagaimana digambarkan De Rooy, tahap pertama adalah munculnya perkampungan semacam "banjar" atau "kabul" yang terdiri dari orang yang berasal dari satu suku asal. Pemukiman tahap perdana ini berada di puncak bukit atau lereng gunung dengan bentuk rumah yang masih sederhana di mana mereka masih tinggal dalam dangau-dangau yang sederhana. Kemudian tahap kedua adalah perkampungan yang terdiri dari dua suku asal disebut dengan "taratak". Taratak berarti bercocok tanam, sementara kampung tempat tinggal mereka disebut dusun. Dusun inilah yang sesungguhnya merupakan pemukiman tahap kedua.

Tahap ketiga adalah munculnya perkampungan yang terdiri dari tiga kelompok suku asal yang disebut dengan "koto". Pada mulanya koto merupakan benteng perlindungan. Barulah tahap keempat yaitu munculnya pemukiman permanen yang biasanya terdiri dari sekurangnya empat suku asal yang disebut dengan "nagari". Nagari merupakan pemukiman yang lebih luas, nyaman dan aman.

Cikal bakal lahirnya pemerintahan nagari yang terkenal merupakan khas masyarakat Minangkabau berasal dari nagari Pariangan. Menurut sejumlah pengamat, sistem pemerintahan nagari mirip dengan konsep polis pada masyarakat Yunani kuno yang lebih otonom dan egaliter. Namun, sistem pemerintahan nagari hanya bertahan sampai tahun 1980. Karena, pada tahun 1981, terbitlah undang-undang tentang perubahan sistem pemerintahan di tingkat bawah. Sistem pemerintahan nagari kemudian diganti dengan sistem pemerintah desa sebagaimana yang berkembang pada masyarakat Jawa. Seperti nagari-nagari lainnya di Sumatra Barat, Nagari Pariangan pun beralih menjadi Desa Pariangan (Masly, 2017: 12). Namun kenyataannya, perubahan ini menyebabkan terkikisnya semangat egalitarisme dan kemandirian yang sudah lama dipraktikkan. Perpindahan dari nagari ke desa merupakan sebuah culture shock (kegoncangan budaya), karena perubahan yang terjadi tidak hanya sekedar perubahan struktural, tetapi sekaligus juga perubahan orientasi dan filosofinya (Yunus, 2007).

Pemerintah kemudian mengeluarkan keputusan pemerintah melalui UU Otonomi Daerah pada tahun 1999 yang memberi peluang bagi daerah untuk mengembangkan daerahnya secara mandiri. Kesempatan inipun tidak dilewatkan oleh masyarakat Sumatera Barat. Undang-undang itu kemudian menjadi momentum agar sistem pemerintahan nagari dapat diterapkan kembali. Wacana untuk beralih kembali kepada sistem pemerintahan 
berbentuk nagari (baliak ka nagari) dilangsungkan sejak awal tahun 1999 sampai tahun 2000 terutama di Kabupaten Tanah Datar, Lima Puluh Kota dan Kabupaten Agam (luhak nan tigo). Setelah itu, pemerintahan berbentuk desa pun kemudian berganti kembali menjadi sistem pemerintahan nagari. Regulasi pertama yang mengatur tentang Pemerintahan Nagari pasca kembali ke Nagari di Sumatera Barat adalah Peraturan Daerah Sumatera Barat Nomor 9 tahun 2000 tentang Ketentuan Pokok Pemerintahan Nagari (Afwadi, 2010). Pariangan pun kembali berganti nama dari desa Pariangan menjadi nagari Pariangan.

\section{Eksistensi Prasasti Tungku Tigo Sejarang di Nagari Tuo Pariangan}

Nagari Pariangan mulai mendapat banyak perhatian baik secara nasional maupun internasional setelah terpilih menjadi salah satu dari 5 desa terindah di dunia menurut Travel Budget Magazine USA yang merupakan majalah mengenai pariwisata internasional pada tahun 2012. Selain menyuguhkan pesona keindahan alam berupa panorama alam sebuah kampung tua di daerah ketinggian, nagari ini juga menyuguhkan pesona sejarah yang kental dan menarik. Pesona wisata sejarah yang disuguhkan nagari Pariangan ini membuktikan bagaimana perubahan sosial budaya masyarakat tumbuh dan berkembang untuk waktu yang lama.

Nagari Tuo Pariangan adalah salah satu nagari atau desa yang ada di Kabupaten Tanah Datar. Kabupaten Tanah Datar jika ditinjau dari sisi sejarah mempunyai catatan yang panjang. Keberadaannya tidak bisa dilepaskan dari sejarah serta perkembangan suku Minangkabau yang merupakan salah satu suku dan etnis di Indonesia. Kabupaten Tanah Datar terkenal sebagai "Luhak Nan Tuo" atau daerah yang dituakan. Dari daerah Tanah Datar inilah berasal cerita turun-temurun atau yang lebih dikenal dengan tambo berawal nenek moyang suku Minangkabau dari Nagari Pariangan. Daerah asal dan berkembangnya suku serta budaya Minangkabau adalah Kabupaten Tanah Datar.

Nagari Tuo Pariangan adalah salah satu daerah istimewa di Minangkabau karena merupakan daerah asal-muasal lahirnya kebudayaan dan adat di Minangkabau. Di Nagari Pariangan, terdapat peninggalan-peninggalan sejarah yang masih terlihat dan terjaga hingga saat ini. Tumbuh dan perkembangan kebudayaan dan adat Minangkabau selalu dikaitkan dengan peninggalan-peninggalan sejarah tersebut. Nagari tuo Pariangan mempunyai banyak peninggalan sejarah masa lampau yang dapat dijadikan bukti-bukti 
perihal asal mula terbentuknya suku dan masyarakat Minangkabau. Nagari ini merupakan salah satu kawasan lanskap sejarah dan kawasan lanskap budaya di Sumatera Barat.

Salah satu peninggalan masa lampau yang banyak terdapat di nagari Pariangan adalah prasasti. Peninggalan sejarah dalam bentuk gambar ataupun tulisan yang terdapat pada batu disebut dengan prasasti. Prasasti juga disebut sebagai batu tulis. Beberapa prasasti ditemukan berbahasa Sansekerta dan menggunakan huruf Pallawa. Biasanya sebuah prasasti berisi tentang peristiwa penting sebuah kerajaan atau peristiwa penting yang dialami oleh seorang raja. Prasasti merupakan salah satu sumber sejarah tertulis. Diantara berbagai sumber-sumber sejarah yang ada, sumber sejarah tertulis merupakan sumber sejarah yang paling banyak ditemukan dan diarsipkan. Sumber sejarah tertulis dapat digunakan sebagai sumber informasi untuk mengungkap peristiwa sejarah. Setiap sumber sejarah mempunyai kegunaannya masing-masing untuk mendukung validitas dari suatu penelitian sejarah.

Pada tahun 1340 M, Raja Adityawarman menemukan Prasasti Pariangan. Prasasti ini dapat menandakan bahwa Raja Adityawarman pernah bermukim di nagari ini. Prasasti ini ditemukan di tepi sungai Mengkaweh yang mengalir dari kaki gunung Marapi. Prasasti ini ditemukan di nagari Pariangan, disebelah timur kota Padang Panjang. Secara astronomis, prasasti ini terletak di S $00^{\circ} 27^{\prime} 32.1^{\prime \prime} \mathrm{E} 100^{\circ} 22^{\prime} 31.7^{\prime \prime}$. Nomor inventaris untuk cagar budaya Prasasti Pariangan ini adalah 12/BCB-TB/A/12/2007. Prasasti Pariangan ini merupakan milik nagari Pariangan.

Pada awalnya hanya ada satu batu yang ditetapkan sebagai prasasti Pariangan. Namun setelah diperhatikan lebih lanjut, terdapat dua batu lagi yang terletak tidak terlalu jauh dari batu prasasti Pariangan yang mempunyai ukuran yang lebih kurang sama besar dan jika dilihat dari tempat yang lebih tinggi, ketiga batu tersebut akan membentuk segitiga seperti bentuk tungku tradisional pada zaman dahulu. Karena hal tersebutlah masyarakat sekitar menyebut prasasti tersebut dengan sebutan prasasti tungku tigo sejarang. Sesuai dengan namanya, prasasti ini terdiri dari tiga batu besar dengan jarak antara ketiga batu tersebut yang tidak terlalu jauh namun belum diukur secara pasti berapa jarak antara satu batu dengan batu lainnya.

Yang pertama ditemukan adalah batu yang pertama atau yang awalnya dikenal sebagai batu prasasti Pariangan. Dibatu tersebut terdapat tulisan berhuruf Pallawa dan berbahasa Sansekerta dari periode Hindu dan Buddha yang ditulis oleh raja Adityawarman 
sehingga batu ini dikenal juga sebagai batu basurek. Namun karena sudah aus, tulisan tersebut tidak bisa dibaca dengan jelas. Prasasti ini berbentuk setengah lingkaran yang dipahatkan pada sebuah batu monolit non-artifisial dan terdapat 6 baris tulisan dipermukaannya. Terdapat angka tahun yang sudah aus, tetapi dapat terbaca dua angka yang di depan, yaitu 12. Kondisi prasasti ini sudah terlalu aus, sehingga tidak memadai untuk dibahas lebih lanjut (Istiawan, 2006: 42). Batu pertama ini adalah sejenis batu vulkanik (trachyt) berukuran tinggi 1,6 m, lebar 2,6 m dan tebal 1,6 m. Sementara dua batu lainnya masih dalam proses dipugar dan diukur lebih lanjut.

Pada batu pertama atau batu prasasti Pariangan ini terdapat sebuah mitos. Mitos Batu Prasasti Pariangan tersebut berfungsi bukan sekedar penjelasan dalam suatu kepuasan, tetapi suatu kisah kebangkitan kenyataan yang diceritakan untuk memenuhi tuntutantuntutan religius yang terdalam, hasrat-hasrat dan dorongan moral, kepatuhan-kepatuhan sosial, pernyataan-pernyataan yang bernilai positif dan bahkan kebutuhan praktis. Dalam masyarakat Pariangan yang bersahaja, mitos batu Prasasti Pariangan ini mempunyai fungsi hakiki yakni menggambarkan, memperkuat, dan mengintensifkan serta mencatat keyakinan-keyakinan. Mitos Batu Prasasti Pariangan memberikan kekuatan moralitas bagi kehidupan manusia (Kurnia \& Monanda, 2015: 51-52). Mitos batu prasasti Pariangan ini tidaklah sebuah cerita tanpa arti, melainkan suatu kekuatan aktif yang hidup dan menjadi suatu unsur penting dalam peradaban manusia.

Batu kedua dari prasasti tungku tigo sejarang ini terletak di tanah kosong disekitar perumahan warga sementara batu ketiganya terletak di dekat pekarangan rumah salah satu warga sekitar disana. Batu kedua terletak disebelah kiri batu pertama sementara batu ketiga terletak disebelah kanan dari batu pertama. Jika ingin melihat dengan jelas ketiga batu tersebut membentuk segitiga seperti tungku dapat dilihat dari tingkatan atas rumah salah seorang warga yang terletak di bukit dibelakang batu pertama.

Pengelola situs wisata prasasti Pariangan adalah BPCB Sumatera Barat. BPCB Sumatera Barat terakhir melakukan pendataan terhadap prasasti Pariangan pada bulan Mei 2017. BPCB adalah singkatan dari Balai Pelestarian Cagar Budaya. BPCB merupakan sebuah Unit Pelaksana Teknis (UPT) yang dibentuk oleh Departemen Pendidikan dan Kebudayaan Pemerintah Republik Indonesia untuk secara khusus membidangi pengelolaan kepurbakalaan dengan wilayah kerja meliputi Provinsi Sumatera Barat, Riau, dan Kepulauan Riau. BPCB Sumatera Barat berkedudukan di Provinsi Sumatra Barat, di 
Kabupaten Tanah Datar tepatnya di Kota Batusangkar. Ketiga wilayah tersebut dipilih karena Sumatera Barat sebagai ranah Minangkabau dan Riau serta Kepulauan Riau sebagai ranah Melayu-Islam merupakan daerah dengan peninggalan sejarah dan purbakala yang jumlahnya banyak sekali di Indonesia.

Terdapat Masjid tertua di Sumatera Barat dan juga tertua di Minangkabau berdiri ditengah-tengah prasasti ini bernama Masjid Ishlah. Masjid Ishlah ini dibangun oleh Syeh Burhanuddin dan merupakan pusat penyebaran agama Islam di Kabupaten Tanah Datar. Masjid ini berukuran 16x24 meter dan memiliki atap yang bertingkat tiga yang melambangkan tungku tigo sejarang, bangunan ini berbahan kayu dan memiliki total delapan tiang, empat tiang besar dan empat tiang kecil.

Berdasarkan hasil wawancara penulis dengan Nurni yang merupakan seorang warga asli nagari Pariangan, kegunaan utama tungku tigo sejarang ini adalah untuk tempat memasak orang tua dahulu. Beliau menjelaskan bahwa dahulu orang tua di daerah tersebut memasak menggunakan tungku dari batu besar. Berdasarkan cerita nenek moyang terdahulu, para orang tua didaerah ini dikenal sebagai orang keramat. Hal ini dikarenakan mereka bisa tinggi bisa pendek dan dahulu tungku tiga sejarang ini adalah tempat memasak untuk berbagai kegiatan seperti kegiatan pemuda dan kegiatan-kegiatan lainnya. Saat ini prasasti ini hanya berfungsi sebagai monumen (peringatan).

Proses pemugaran ketiga batu dari prasasti ini mulai dilakukan setelah keluar bantuan dari dinas pariwisata kota Padang pada tahun 2021 ini. Proses pemugaran masih berlangsung hingga saat ini. Pemugaran adalah upaya pengembalian kondisi fisik benda cagar budaya, bangunan dan struktur cagar budaya yang rusak sesuai dengan keaslian bahan, bentuk, tata letak, dan/atau teknik pengerjaan untuk memperpanjang usianya. Sasaran yang ingin dicapai adalah terlaksananya kegiatan pemugaran sesuai dengan keaslian bahan, bentuk, tata letak, dan/atau teknik pengerjaan sehingga dapat dimanfaatkan seluas-luasnya dengan benar untuk kepentingan agama, sosial, pendidikan, ilmu pengetahuan, teknologi, kebudayaan dan pariwisata (Kementerian Pendidikan, 2018: 57$58)$.

Prasasti termasuk kedalam cagar budaya. Pemugaran cagar budaya dilaksanakan melalui proses rekonstruksi, konsolidasi, rehabilitasi dan rekonstruksi yang bertujuan untuk mengembalikan kondisi fisik cagar budaya yang rusak dengan memperbaiki, memperkuat dan mengawetkannya. Tahapan dapat dijelaskan yaitu; 1) Rekonstruksi, 
merupakan upaya membuat bangunan cagar budaya dan struktur cagar budaya kembali sesuai kondisi yang diketahui sebelumnya dengan tetap mengutamakan prinsip keaslian bahan, teknik pengerjaan dan tata letak, termasuk dalam menggunakan bahan baru sebagai penggganti bahan asli. 2) Konsolidasi, merupakan upaya memperbaiki bangunan cagar budaya dan struktur cagar budaya agar konstruksinya menjadi lebih kuat dan tidak cepat rusak. 3) Rehabilitasi, merupakan proses perbaikan dan pemulihan bangunan dan struktur cagar budaya dengan fokus utama kegiatannya untuk penanganan yang bersifat parsial. 4) Restorasi, merupakan serangkaian kegiatan yang dilakukan dengan maksud agar keaslian bentuk bangunan dan struktur cagar budaya bisa kembali kebentuk awal namun tindakan ini harus dapat dipertanggungjawabkan secara ilmiah.

Peran pemerintah sangat penting dalam upaya pelestarian dan kelangsungan suatu cagar budaya. Pemerintah bertugas mengatur perlindungan, pengembangan dan pemanfaatan suatu cagar budaya secara maksimal. Masing-masing cagar budaya mempunyai nilai historis yang tidak ternilai harganya. Untuk itu pemerintah berusaha meningkatkan kualitas sumber daya manusia pengelola pelestarian cagar budaya agar mereka bisa memastikan setiap cagar budaya terus lestari dan bermanfaat bagi kehidupan masyarakat disekitarnya. Suatu kegiatan pelestarian cagar budaya harus selalu bisa dipertanggungjawabkan secara akademis, teknis dan administratif sehingga pemugaran cagar budaya adalah pekerjaan yang spesifik. Prosedur studi atau penilaian harus terpenuhi sebagaimana dengan ketentuan yang dipersyaratkan sebelum melakukan pemugaran.

Selain melakukan proses pemugaran prasasti, pemerintah kota Padang juga akan membuat jalan sepeda motor dan tangga agar situs prasasti ini dapat mudah diakses oleh pengunjung. Seperti yang sama-sama kita tahu bahwa akses kesebuah situs sejarah atau cagar budaya merupakan hal yang amat penting. Orang tentunya akan memilih berkunjung ke suatu objek sejarah yang mudah diakses dan berada dilingkungan yang kondusif sehingga orang-orang yang berkunjung akan merasa aman dan nyaman.

Selain prasasti Pariangan, masih banyak lagi peninggalan-peninggalan sejarah beserta kebudayaan yang terdapat di nagari Pariangan. Beberapa contoh objek-objek sejarah yang ada di nagari Pariangan ini seperti Masjid Ishlah, Gerbang Biaro, Balai Saruang, Kuburan Panjang, Balai Panjang, Situs Sandi Laweh, Makam Tantejo Gurhano, Makam-makam keramat, Balai Katiak, Balai Pasujian, Galundi nan baselo, Sawah Setampang Baniah, Lesung Gadang dan lain sebagainya. 


\section{Kesimpulan}

Nagari pertama di ranah Minang adalah Nagari Pariangan. Di Nagari Pariangan, terdapat peninggalan-peninggalan sejarah yang masih terlihat dan terjaga hingga saat ini. Salah satu peninggalan masa lampau yang banyak terdapat di nagari Pariangan adalah prasasti. Pada tahun 1340 M, Raja Adityawarman menemukan Prasasti Pariangan. Prasasti ini dapat menandakan bahwa Raja Adityawarman pernah bermukim di nagari ini. Prasasti ini ditemukan di tepi sungai Mengkaweh yang mengalir dari kaki gunung Marapi di Nagari Pariangan. Pada awalnya hanya ada satu batu yang ditetapkan sebagai prasasti Pariangan. Namun setelah diperhatikan lebih lanjut, terdapat dua batu lagi yang terletak tidak terlalu jauh dari batu prasasti Pariangan yang mempunya ukuran yang lebih kurang sama besar dan jika dilihat dari tempat yang lebih tinggi, ketiga batu tersebut akan membentuk segitiga seperti bentuk tungku tradisional pada zaman dahulu. Karena hal tersebutlah masyarakat sekitar menyebut prasasti tersebut dengan sebutan prasasti tungku tigo sejarang. Pada tahun 2021 ini, dinas pariwisata dari kota Padang mengeluarkan bantuan dan mulai melakukan pemugaran pada ketiga batu dari prasasti ini. Proses pemugaran masih berlangsung hingga saat ini.

\section{Daftar Rujukan}

Afwadi. (2010). Penyelenggaraan Pemerintahan Nagari: Antara Format Adat Atau Format Negara. Juris, 9(1), 47-60.

Amir, A. (2006). Adat Minangkabau Pola dan Tujuan Hidup Orang Minang. Jakarta: PT. Mutiara Sumber Widya.

Amir, A. (2011). Adat Minangkabau pola dan tujuan hidup orang Minang. Jakarta: Citra Harta Prima.

Diradjo, I. D. S. (2017). Tambo Alam Minangkabau Tatanan Adat Warisan Nenek Moyang Orang Minang. Bukittinggi: Buku Alam Minangkabau Kristal Multimedia.

Erwin, M. S., Warhat, Z., \& Syafwandi, S. (2021). Brand Identity Nagari Pariangan, Desa Terindah di Dunia Kabupaten Tanah Datar, Sumatera Barat. Besaung: Jurnal Seni Desain dan Budaya, 4(1).

Irman, I., Murisal, M., Syafwar, F., Silvianetri, S., Zubaidah, Z., \& Yeni, P. (2020). Membangun Kesadaran Spritual Melalui Konseling Berbasis Surau dalam Pengembangan Pariwisata. Islamic Counseling: Jurnal Bimbingan Konseling Islam, 4(1).

Istiawan, B. (2006). Selintas Prasasti dari Melayu Kuno. Batusangkar: Balai Pelestarian Peninggalan Purbakala Batusangkar. 
Kementerian Pendidikan, K. (2018). Teknis pemugaran cagar budaya. depok: Pusat Pendidikan dan Pelatihan Pegawai Kementrian Pendidikan dan Kebudayaan. Retrieved from https://pusdiklat.kemdikbud.go.id/file/e-publikasi/02.

Kurnia, F. E. \& Monanda, R. (2015). Folklor Minangkabau Mitos Batu-Batu dan Cerita Rakyat di Luhak Nan Tuo. Padang: Suri (Surau Institute For Conservation).

Madjid, M. D., \& Wahyudhi, J. (2014). Ilmu Sejarah: Sebuah Pengantar. Jakarta: Kencana.

Masly, D., \& Arief, A. M. R. (2017). Potensi Daya Tarik Wisata Nagari Tuo Pariangan Sebagai Kawasan Desa Wisata Pariangan Kabupaten Tanah Datar Sumatera Barat. Skripsi. Universitas Riau.

Melinda, N. (2006). Pembangunan Berbasis Kelembagaan Adat: Sebuah Alternatif Pembelajaran dari Kasus Kinerja Kelembagaan Nagari dalam Wilayah Perencanaan di Propinsi Sumatera Barat. Jurnal Mimbar, 22(2), 234-257.

Herlina, N. (2020). Metode Sejarah. Bandung: Satya Historika.

von Benda-Beckmann, F. (2001). On the reproduction of law: Micro and macro in the time-space geography of law. In Begegnung und Konflikt-eine kulturanthropologische Bestandsaufnahme (pp. 119-131).

Salim, S., \& Syahrum, S. (2012). Metodologi Penelitian Kualitatif. Bandung: Citapustaka Media.

Tanamir, M. D. (2017). Pengembangan Objek Wisata Panorama Tertinggal Di Kabupaten Tanah Datar. Jurnal Spasial: Penelitian, Terapan Ilmu Geografi, dan Pendidikan Geografi, 5(1), 131449.

Yunus, Y. (2007). Model Pemerintahan Nagari Yang Partisipatif dalam Masyarakat Minangkabau. Jurnal Demokrasi, 6(2).

Zainuddin, M. (2013). Minangkabau dan Adatnya. Yogyakarta: Penerbit Ombak. 